\title{
Peningkatan kemampuan berpikir statistis mahasiswa melalui challenge-based learning dengan strategi konflik kognitif
}

\author{
Wati Susilawati', Ridha Abdullah', Ida Rosyidah ${ }^{3}$ \\ 1. 3. Fakultas Tarbiyah dan Keguruan UIN SGD Bandung, \\ 2. Fakultas Dakwah dan Komunikasi UIN SGD Bandung, \\ wati85@uinsgd.ac.id
}

DOI : $10.15575 /$ ja.v5i1.4808

Received: 24 Januari 2019 ; Accepted: 08 Mei 2019 ; Published: 29 Juni 2019

\begin{abstract}
Abstrak
Tujuan penelitian mengkaji secara komprehensif perbedaan peningkatan kemampuan berpikir statistis mahasiswa calon guru melalui pembelajaran Challenge-Based Learning dengan Strategi Konflik Kognitif. Metode yang digunakan adalah Quasi Eksperiment dengan desain penelitian Nonequivalent Pretest-Posttest Control Group, melibatkan sampel dua kelas mahasiswa Sekolah Tinggi Agama Islam di Sumedang. Instrumen yang digunakan tes berpikir statistis. Hasil penelitian menunjukkan adanya perbedaan peningkatan kemampuan berpikir statistis antara mahasiswa yang pembelajaran challenge-based learning dengan strategi konflik kognitif memperoleh peningkatan lebih tinggi dari mahasiswa yang pembelajarannya ekspositori, baik secara keseluruhan mahasiswa maupun berdasarkan pengetahuan awal statistis.Terdapat interaksi antara jenis (pembelajaran challenge-based learning dengan strategi konflik kognitif dan ekspositori) dan kategori pengetahuan awal statistis (pandai, cukup, lemah) terhadap peningkatan kemampuan berpikir statistis mahasiswa. Pembelajaran berbasis tantangan dengan strategi konflik kognitif dapat memfasilitasi proses konflik, proses penemuan, proses interaksi sosial, dan proses reflektif mahasiswa sehingga kemampuan berpikir statistis mahasiswa lebih baik dari pada pembelajaran ekspositori.
\end{abstract}

Kata Kunci: Berpikir Statistis, Challenge-Based Learning, Konflik Kognitif

\begin{abstract}
The purpose of the study is to comprehensively examine the differences in the increase of prospective students in statistical thinking skills through Challenge-Based Learning with Cognitive Conflict Strategies. The method was Quasi Experiment with the Nonequivalent Pretest-Posttest Control Group research design, involving a sample of two student classes at the Islamic College in Sumedang. The instrument used statistical thinking tests. The results showed differences in the increase in statistical thinking skills between students whose challenge-based learning with cognitive conflict strategies gained a higher increase than students who had expository learning, both overall students and based on statistical initial knowledge. There are interactions between types (challenge-based learning with cognitive and expository conflict strategies) and statistical initial knowledge categories (clever, sufficient, weak) towards increasing students' statistical thinking skills. Challenge-based learning with cognitive conflict strategies can facilitate conflict processes, discovery processes, social interaction processes, and student reflective processes so that students' statistical thinking skills are better than expository learning.
\end{abstract}

Keyword: Statistical Thinking, Challenge-Based Learning, Cognitive Conflit

\section{PENDAHULUAN}


Pada era globalisasi, statistik memegang peran penting dalam berbagai aktivitas manusia. Dalam melakukan perencanan, penelitian, dan pengambilan keputusan, bidang pendidikan, sosial, politik, ekonomi, budaya, kesehatan, dan perindustrian. Sesuai ungkapan (Eunsil, Jiyoung, \& Haeyoung. 2014), Sudah menjadi perhatian khusus setiap jenjang sekolah maupun perguruan tinggi menjadikan statistik wajib dipelajari seluruh peserta didik dalam desain studi ilmiah, analisis data ilmiah, interpretasi hasil, dan penarikan pernyataan konklusif. Berdasarkan konten dan kesulitan materi tidak dapat dipungkiri, bahwa sebagian mahasiswa berpandangan bahwa belajar statistika itu sulit dan kurang menyenangkan. Sebagaimana diidentifikasi Verhoeven (2006); (Martadipura 2012) bahwa adanya phobia terhadap statistika, berakibat kurang minat untuk mempelajarinya, kekuatiran yang berlebihan terhadap abstraknya materi menimbulkan kecemasan terhadap motivasi dan tidak senang belajar.

Beberapa temuan ternyata menunjukkan keadaan yang masih belum menggembirakan, sekaligus menjadi gambaran bahwa perlu pengembangan lebih lanjut dari upaya yang dilakukan sebelumnya. Garfield, (1995); (Tishkovskaya \& Lancaster 2010), mengungkap adanya kekurangan pengetahuan statistika dasar yang dimiliki mahasiswa, pembelajaran statistik tidak diberdayakan untuk menerapkan aspek-aspek pengetahuan statistika untuk memecahkan permasalahan umum yang timbul dari konteks realita kehidupan, kemampuan berpikir statistik mahasiswa yang sedang mengikuti perkuliahan statistika dasar masih belum optimal, berada pada level transitional dan quantitative. Hanya sebagian kecil mahasiswa yang kemampuan berpikir statistisnya pada level analitical.

Jones, G.A., Thornton, C.A., Langrall, C.W., Mooney, E., Perry, B., \& Putt, I. (2000); BenZvi \& Friedlander (2010) menyatakan bahwa pembelajaran statistika konvensional biasanya hanya menekankan perhitungan dan hapalan, mengabaikan pengembangan pandangan terpadu yang lebih luas dari pemecahan masalah statistik. Siswa mendapatkan statistika dari kurikulum berbentuk sekumpulan materi yang terpisahpisah, teknik pembelajaran tidak bermakna.
Garfield, (1995); (Martadiputra 2012), mengungkap bahwa mahasiswa S1 yang sedang mengikuti perkuliahan statistika dasar masih belum optimal, berada pada level transitional dan quantitative. Hanya sebagian kecil mahasiswa yang kemampuan berpikir statistisnya pada level analitical.

Temuan Tishkovskaya \& Lancaster (2010), kurangnya kemampuan berpikir statistis disebabkan ketidakmampuan mahasiswa untuk mengaplikasikannya dalam kehidupan sehari-hari. Kemampuan berpikir statistis dapat dikembangkan melalui tugas-tugas penalaran yang menantang dalam proses pembelajaran. Sangatlah penting bagaimana pembelajar dapat memberikan kesempatan belajar yang variatif berasal dari keterlibatan mahasiswa dalam tugas-tugas yang menantang (Diezmann C. M., 2005). Penalaran mental tingkat tinggi seseorang menentukan peran berpikir statistis dalam proses berpikir intelektual, sangat mempengaruhi kesuksesan individu dalam mengatasi permasalahan real-world.

Berpikir statistis dikemukakan oleh Delmas (2002); (Martadipura 2012) sebagai kemampuan untuk mengerti proses statistis secara keseluruhan meliputi: proses pengambilan data, pembuatan instrumen, penentuan variabel, dan kemampuan menjawab permasalahan yang ada. Sementara Chance (2002); (Martadipura, 2012) menyatakan bahwa berpikir statistis melibatkan pemahaman tentang seluruh proses investigasi mulai dari pernyataan yang diajukan untuk pengumpulan data, memilih analisa yang akan digunakan untuk pengujian asumsi; memahami bagaimana model yang dapat digunakan untuk mensimulasikan fenomena acak; memahami bagaimana data yang dihasilkan untuk memperkirakan probabilitas; mengakui bagaimana, kapan, mengapa, alat penyelidikan dapat digunakan; dan mampu memahami serta memanfaatkan konteks suatu masalah untuk merencanakan dan mengevaluasi penyelidikan dan untuk menarik kesimpulan.

Berdasarkan penelaahan terhadap hasil penelitian dan model perkembangan kognitif dari Biggs \& Collis (1991); Jones Jones, G.A., Langrall, C. W., Thornton, C. A., \& Mogill, A.T (1999), (Martadipura 2012) merumuskan karakteristik berpikir statistik melalui empat 
konstruksi, yaitu: (1) mendeskripsikan tampilan data, (2) mengorganisasikan dan mereduksi data, (3) merepresentasikan data, (4) menganalisis dan menginterpretasikan data. Untuk mengukur tingkat kemampuan berpikir statistik, modifikasi tahapan berpikir kognitif model Structure of the Observed Learning Outcomes (SOLO) dari Biggs \& Collis (1991) yang dilakukan oleh Jones, G.A., Thornton, C.A., Langrall, C.W., Mooney, E., Perry, B., \& Putt, I. (2000); (Martadipura 2012) yaitu: (1) Idiosyncratic; (2) Transitional; (3) Quantitative; (4) Analytical.

Karakteristik statistika yang bersifat abstrak itu menjadikan statistik sulit dipahami karena pola pembelajaran cenderung textbookoriented yang tidak banyak terkait dengan realitas kehidupan sehari-hari. Kecenderungan dalam proses penyelesaian soal masih konvergen, soal-soal statistika yang diberikan masih bersifat close problem yakni tipe masalah yang terlalu prosedural, mahasiswa cenderung kurang mendapat kesempatan untuk mencari alternatif lain dalam menyelesaikan permasalahan yang diberikan, tidak ada kebebasan menggunakan idea-idea original dalam menafsir kenyataan.

Pembelajaran masih cenderung menekankan formulasi konsep atau kemampuan mereproduksi verbal, numerik, ataupun menghapal rumus. Beban mata kuliah telah mempersempit ruang bagi mahasiswa untuk mengembangkan kepribadiannya sebagai calon sarjana yang mandiri yang mampu memproses lingkungan sosialnya secara kreatif.

Kompleksitas dan beragamnya permasalahan pendidikan ditinjau dari sisi kemampuan dan kebutuhan mahasiswa, lingkungan sosial, kemajuan ilmu pengetahuan dan teknologi, serta tuntutan masyarakat menyebabkan proses pendidikan menjadi semakin kompleks. Kondisi seperti di atas kurang memberi perubahan terhadap perkembangan dunia pendidikan di era globalisasi ini. Fenomena ini sekaligus menunjukkan bahwa pembelajaran statistika di Indonesia masih perlu evaluasi ulang secara komprehensif. Terutama kompetensi guru dan calon guru dalam membangun pemahaman melalui proses berpikir statistik.
Australian Education Council (1994), School Curriculum and Assessment Authority \& Curriculum and Assessment Authoritybfor Wales (1996); (Jones, G.A., Langrall, C.W., Thornton, C.A., Mooney, E.S., Wares, A.S., Jones, M.R., Perry, B., Putt, I.J., \& Nisbet, S. 2001) mengungkapkan perlu adanya reformasi pendidikan statistika di semua jenjang pendidikan, dianjurkan untuk menggunakan pendekatan yang lebih luas dalam mempelajari statistika, meliputi: mendeskripsikan, mengorganisasikan, merepresentasikan, menganalisis, dan menginterpretasikan data. Untuk memperluas perspektif ini dibutuhkan penelitian yang penuh tantangan selama belajar dan pembelajaran statistika.

Mata kuliah statistik penelitian pendidikan, merupakan mata kuliah wajib, yang harus ditempuh mahasiswa PAI, Mata kuliah ini diberikan kepada mahasiswa semester IV, serta menjadi mata kuliah prasyarat bagi mahasiswa yang akan menyusun skripsi. Kompetensi umum mata kuliah ini adalah mahasiswa dapat berpikir statistis dari permasalahan skripsi yang akan ditelitinya, serta dapat menggunakan beberapa alat uji statistik dalam menganalisis data, dapat mengomunikasikan hasil penelitian yang dilakukan baik secara lisan maupun tulisan.

Kompetensi inilah yang perlu dimiliki mahasiswa calon guru, sehingga mereka dapat berpikir statisis dan menyikapi berbagai informasi terkait dengan statistika, serta dapat memberi makna dan menemukan solusi dari permasalahan statistik.

Selain kenyataan empiris, terdapat beberapa faktor lain yang dapat berkontribusi terhadap kemampuan berpikir statistis mahasiswa yaitu Pengetahuan Awal Statistika (PAS). Dikategorikan ke dalam tiga kelompok yaitu: pandai, cukup, dan lemah dengan pertimbangan variatifnya jurusan di kelas dengan latar belakang berbeda, dalam satu kelas terdapat jurusan IPA, IPS, Bahasa, dan SMK. Hal ini menyebabkan kemampuan dasar yang dimiliki tiap mahasiswa beragam, Teknis PAS bertujuan untuk mengetahui kesetaraan antara kelompok eksperimen dan kelompok kontrol yang masing-masing sampel penelitian memiliki pengetahuan statistik dalam kondisi awal yang sama. Selain itu pengkategorian tersebut untuk mengetahui 
perbedaan perlakuan pada setiap kategori terhadap mahasiswa selama proses pembelajaran.

Pembelajaran yang tepat dengan pengaturan lingkungan belajar memiliki pengaruh yang signifikan terhadap kesuksesan pelaksanaan proses pembelajaran statistika yang dapat melibatkan mahasiswa secara aktif dinamik, kreatif, dan generik yang akhirnya dapat mengembangkan kemampuan, menumbuhkan motivasi, dan potensi secara optimal dalam belajar statistika sesuai dengan tuntutan era penuh perubahan. Salah satu alternatif yang diduga akan dapat mengatasi permasalahan tersebut adalah menerapkan Pembelajaran Challenge Based Learning (CBL) dengan strategi Konflik Kognitif.

Keunggulan integrasi pendekatan CBL dengan strategi konflik kognitif antara lain, setting pembelajaran mempasilitasi interaksi antar mahasiswa aktif berpikir mengkonstruksi, merencanakan pemecahan masalah yang muncul melalui interaksi dengan lingkungan, sehingga muncul konflik kognitif sebagai stimulus untuk memahami dan menentukan organisasi dan sifat alami tentang apa yang dipelajari, dimana konflik kognitif selalu diupayakan timbul dalam proses pembelajaran, yang melandasi pengetahuan berkembang melalui interaksi sosial dan negosiasi (Susilawati 2017).

Strategi konflik yang digunakan dalam penelitian ini adalah konflik kognitif menurut teori Piaget dimana konflik terjadi karena perbedaan antara struktur kognitif seseorang dengan informasi yang berasal dari lingkungan. dan konflik kognitif teori Hasweh; dimana terjadi pertentangan antara skemata-skemata struktur kognitif yang lama dengan struktur kognitif yang baru yang sedang dipelajari, tidak hanya berkaitan dengan prakonsepsi/konsepsi baru yang dipelajari dalam suatu waktu tetapi juga kepercayaan, substruktur, total struktur, atau sesuatu yang berada pada struktur kognitif (Ismaimuza, 2010).

Pembelajaran yang dapat mengatasi permasalahan yang memacu mahasiswa belajar dari tugas, bahan ajar, dan proyek pembelajaran, dengan mengonsrtuksi sendiri masalah divergen yang distimulasi secara kontekstual, yang memicu mahasiswa tertantang untuk mengeksplorasi proyeknya di depan kelas, bahkan mempersiapkan calon guru profesional dimasa yang akan datang tidak hanya mengandalkan pengetahuan yang diperoleh sendiri, keterlibatan pembelajar dan pebelajar lain merekonstruksi konsep materi pembelajaran untuk mengatasi konflik, serta latihan menyelesaikan tugas yang berkesinambungan sangat dibutuhkan untuk memenuhi tantangan dari permasalahan. Menurut Shaidullina, A. R., Pavlova, N. A., Minsabirova, V. N., Burdukovskaya, E. A., Yunusova, A. B., Letyaev, V. A., Afanasev, A. S. (2015b); (Susilawati2017) kualitas sistem pendidikan selalu berubah sesuai kebutuhan di masyarakat yang melibatkan pengembangan potensi mahasiswa.

Penerapan pembelajaran berbasis tantangan terdiri dari tiga bagian penting yaitu Pembelajaran berbasis masalah, pembelajaran kontekstual dan pembelajaran berbasis proyek. Pembelajaran berbasis tantangan dipandang sebagai pembelajaran yang mampu mengimplementasikan tuntutan mahasiswa untuk bekerja keras menggunakan daya fikirnya ketika dihadapkan dengan situasi masalah yang bertentangan dengan struktur kognitifnya, maka terjadilah konflik yang pada akhirnya akan terjadi perubahan pemahaman dan terbentuklah pengetahuan baru bagi mahasiswa (Lee, G., Kwon, J., Park, S. S., Kim, J. W., Kwon, H.G.,\& Park, H. K. (2003); (Susilawati, 2017). Sintaks pembelajaran berbasis tantangan dengan strategi konflik kognitif adaftasi Johnson, Laurence F.; Smith, Rachel S.; Smythe, J. Troy; Varon, Rachel K. (2009); (Susilawati, 2017) meliputi:

1. Desain proses pembelajaran diawali orientasi gagasan utama mengenai tugas yang harus disepakati mahasiswa khususnya terkait konstruksi konsep statistik dalam merancang desain skenario bahan ajar, lembar kerja mahasiswa, dan projek kelompok, yang jadi kajian masing-masing mahasiswa calon guru secara inquiri. Menjelaskan tujuan pembelajaran dan aktivitas tantangan yang memunculkan konflik kognitif yang diharapkan dilakukan mahasiswa terkait tugas yang diberikan.

2. Memfasilitasi mahasiswa untuk mengajukan pertanyaan yang 
memunculkan konflik kognitif mengenai tindak lanjut tugas yang mereka peroleh.

3. Memberi kesempatan dan tantangan kepada mahasiswa untuk kolaborasi kaitannya dengan konflik kognitif dalam mendesain skenario pembelajaran sebagai projek dengan cara penyelidikan, menganalisis, mengajukan dugaan, mengembangkan contoh-contoh yang sudah ada untuk mencari alternatif yang baru, agar disimulasikan keterampilan spesifiknya di depan kelas melalui eksplorasi untuk mengkonstruk konsep statistik.

4. Membimbing untuk meningkatkan rasa ingin tahu (curiosity) pada proses investigasi individual dan kelompok. Secara mandiri mahasiswa berusaha untuk memahami, melakukan penyelidikan terhadap tugas yang diberikan, mengeksplorasi, melakukan percobaan serta berusaha menyelesaikan konflik kognitif dengan menggunakan pengetahuan awal mereka. Hasil investigasi dan eksplorasi diinterpretasikan melalui kegiatan diskusi, tanya jawab untuk memperkaya dan mempertajam proses penyelesaian tugas. Dalam hal ini pengajar berperan sebagai fasilitator yang memandu mahasiswa pada pelakasanaan proses kolaborasi kelompok kecil, memberi sugesti untuk mengeksplorasi ide-ide matematis, mengajukan karakteristik pertanyaan di atas parameter kwalitas mahasiswa yang memunculkan konflik kognitif, yang relevan dengan tugas, dan memberikan contoh-contoh untuk mengklarifikasi problem jika muncul, mahasiswa mengidentifikasi semua teknik penyelesaian tugas berdasarkan perspektif berbagai aspek (analisis, sintetis, dan evaluasi).

5. Mengembangkan hasil kolaborasi kelompok kecil berupa kesepakatan dan kesepahaman terhadap tugas yang melibatkan konflik kognitif untuk mengkonstruk konsep/topik yang dikaji menurut kreasinya masing-masing. Mahasiswa dituntut mampu menghasilkan suatu karya kreativitas berupa vidio dokumentasi dan artikel ilmiah dari pengembangan tugas, sehingga apa yang telah dipelajarinya bermakna. Hasil kreasi merupakan produk kreatif berupa media pembelajaran sehingga dapat diperagakan dan dipresentasikan di depan kelas, untuk ditindak lanjuti dalam proses kompleksitas pengkonstruksian formula konsep statistik. Sementara mahasiswa pada kelompok lain memberi tanggapan.

6. Mengevaluasi dan merefleksi proses pengonstruksian konsep statistik sebagai solusi. Aktivitas demikian merupakan salah satu komponen CBL dengan strategi konflik kognitif yang dapat membantu mahasiswa mengkonsolidasikan pengetahuan yang telah diperoleh terhadap proses penyelesaian tugas. Hasil re-kreasi merupakan produk kreatif sehingga dapat dipresentasikan, dipajang atau ditindak lanjuti untuk dipublikasi.

7. Evaluasi dilakukan selama proses pembelajaran dan pada akhir pembelajaran. Selama proses pembelajaran, evaluasi dilakukan dengan mengamati sikap kegigihan dalam berpikir statistik mahasiswa. Melalui format observasi aktivitas mahasiswa, Hal-hal yang dinilai selama proses pembelajaran adalah kesungguhan mengerjakan tugas, hasil eksplorasi, kemampuan memberi argumen dalam konteks berpikir statistis, kemampuan berkolaborasi dalam memikul tanggung jawab. Pada setiap akhir proses pembelajaran dilaksanakan tes. Dan evaluasi terhadap produk kreatif yang dihasilkan mahasiswa. Kriteria penilaian disepakati bersama pada waktu orientasi.

Secara eksplisist masalah penelitian ini adalah sebagai berikut: (a) Apakah peningkatan kemampuan berpikir statistis antara mahasiswa yang mengikuti pembelajaran challenge-based learning dengan strategi konflik kognitif lebih tinggi dari pada mahasiswa yang pembelajaran ekspositori berdasarkan keseluruhan mahasiswa?, (b) Apakah peningkatan kemampuan berpikir statistis antara mahasiswa yang mengikuti pembelajaran challenge-based learninglebih tinggi dari pada mahasiswa yang pembelajaran ekspositori ditinjau berdasarkan Pengetahuan Awal Statistik (PAS) mahasiswa dalam level pandai, cukup, lemah?, (c) Apakah terdapat interaksi antara jenis (pembelajaran challenge-based learning dengan strategi konflik kognitif dan 
ekspositori) serta kategori PAS (pandai, cukup, lemah) terhadap peningkatan kemampuan berpikir statistis mahasiswa?.

\section{METODE PENELITIAN}

Desain Penelitian Nonequivalent Pretestposttest Control Group Design, kelompok eksperimen dan kontrol dianalisis perbedaan peningkatan kemampuan berpikir statistis. Metode Quasi-Eksperiment dengan tidak adanya random sampel penelitian, tetapi random kelompok digunakan sebagai dasar untuk menetapkan kelompok eksperimen yang menggunakan pendekatan ChallengeBased Learning dengan strategi konflik kognitif dan kelompok kontrol mendapatkan pembelajaran ekspositori. Populasi adalah mahasiswa jurusan PAI di STAI Kabupaten Sumedang, melibatkan sampel mahasiswa semester IV yang menempuh mata kuliah statistik pendidikan, kelas A sebagai kelas eksperimen, dan kelas B sebagai kelas kontrol. Analisis data menerapkan uji-t indevendent dan ANOVA dua jalur.

\section{TEMUAN DAN PEMBAHASAN}

Persentase peningkatan kemampuan berpikir statistis baik secara keseluruhan mahasiswa maupun berdasarkan PAS. Rerata persentase $N$-gain untuk setiap indikator berpikir statistis mahasiswa, baik kelompok eksperimen yang mendapatkan pembelajaran challenge-based learning dengan strategi konflik kognitif dan kelompok kontrol dengan pembelajaran ekspositori.

Rerata persentasi $<$ g $>$ kemampuan berpikir statistis memperlihatkan bahwa kelompok eksperimen pada level pandai mengalami peningkatan sebesar 56\%. Sedangkan rerata persentase terkecil kemampuan berpikir statistis kelompok kontrol berada pada level cukup sebesar $32 \%$.

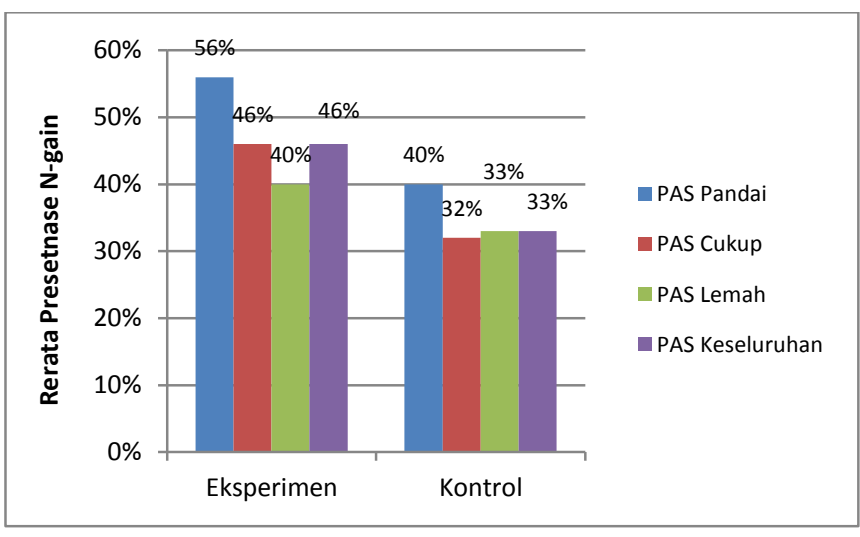

\section{Gambar 1. Rerata Presetnase N-Gain Kemampuan Berpikir Statistis Mahasiswa Berdasarkan Keseluruhan Dan Pengetahuan Awal Statistik}

Berdasar kategori pengetahuan awal Statistik (PAS) pada level pandai, cukup dan lemah bahwa pembelajaran challenge-based learning dengan strategi konflik kognitif memberikan kontribusi lebih baik dalam meningkatkan kemampuann berpikir statistis mahasiswa. Sesuai ungkapan (Susilawati, 2017) bahwa strategi konflik kognitif dapat membantu mahasiswa dalam merekontruksi pengetahuan yang hendak dipelajari dengan pengetahuan yang dipelajari sebelumnya.

Sebelum proses pembelajaran challengebased learning dengan strategi konflik kognitif, mahasiswa dituntut dapat menyelesaikan projek pembuatan media pembelajaran untuk mengkonstruksi formula konsep statistik yang mau digunakan dalam eksplorasi kolaborasi kooperatif di kelas. Choi \& Johnson, (2005); (Susilawati 2017) mengungkap bahwa pembelajaran dengan media akan meningkatkan motivasi dan kebermaknaan proses belajar mahasiswa. Shabiralyani, G., Hasan, K. S., Hamad, N., \& Iqbal, N. (2015); (Surijah, A, E., Anggara, Yanti, Sari, Hartika, Ramayanti, Sugiri, 2018) menyatakan media pembelajaran merupakan salah satu faktor yang berpengaruh terhadap prestasi belajar, mayoritas pembelajar dan pebelajar memiliki persepsi positif terhadap penggunaan media dalam proses pembelajaran.

Diagram di bawah ini, memperlihatkan bahwa rerata persentase peningkatan tiap indikator kemampuan berpikir statistis Mendeskripsikan Tampilan Data (MTD), 
Mengorganisasikan (M), Mereduksi Data (MRD), Merepresentasikan Data (M), serta Interpretasi Data (ID) kelompok eksperimen secara keseluruhan dan pengetahuan awal statistik lebih tinggi dari kelompok kontrol.

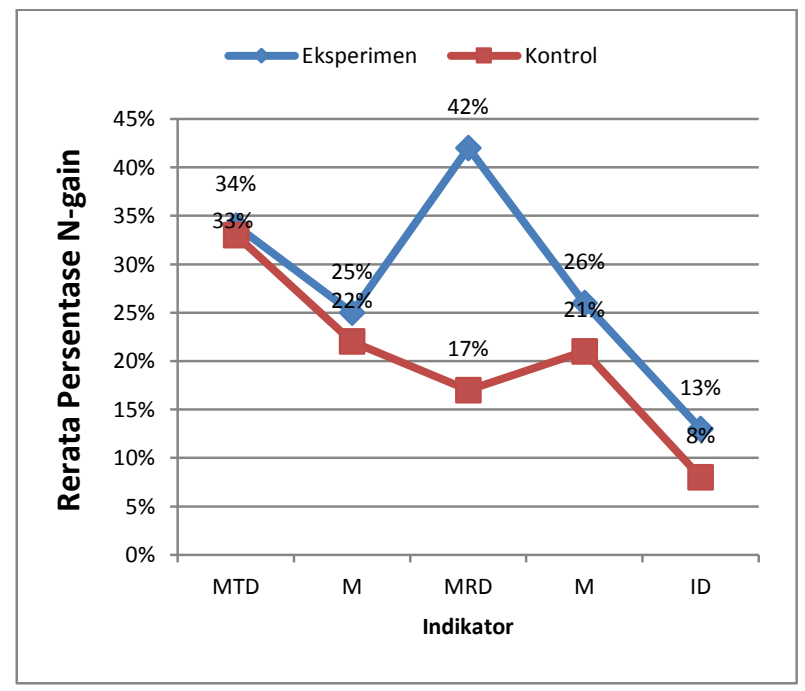

\section{Gambar 2. Diagram Rerata Persentase $<$ g $>$ tiap Indikator Berpikir Statistik Mahasiswa}

Berdasarkan deskripsi terhadap hasil-hasil tersebut, maka dapat disimpulkan bahwa secara keseluruhan mahasiswa dan PAS kemampuan berpikir statistis (BS) rerata persentase $<\mathrm{g}>$ kelompok eksperimen lebih tinggi dari kelompok kontrol. Perbedaan ini mengindikasikan bahwa penerapan pendekatan pembelajaran challenge-based learning dengan strategi konflik kognitif memberikan kontribusi lebih baik dari pembelajaran ekspositori dalam upaya meningkatkan kemampuan berpikir statistis mahasiswa. Sesuai hasil temuan Susilawati (2017) pembelajaran challenge-based learning dengan strategi konflik kognitif dapat meningkatkan kemampuan visualisasi spasial dan berpikir lateral matematis mahasiswa.

Perbedaan peningkatan tersebut dikarenakan keunggulan pembelajaran CBL dengan strategi konflik kognitif, memfasilitasi mahasiswa untuk bereksplorasi dan terlibat aktif dalam melakukan tantangan transformasi idea-idea kreatif. Refleksi dalam tantangan yang dilakukan merupakan kunci utama kekuatan pembelajaran tersebut. Pentingnya proses refleksi, Susilawati (2017) mengungkapkan bahwa prinsip utama berpikir dalam proses pembelajaran CBL adalah melibatkan refleksi setelah terlaksananya tantangan dan kolaborasi, dengan memberikan umpan balik, bersifat interaktif yang muncul melalui proses kolaborasi kelompok kecil. Relevan dengan hal tersebut karakteristik lingkungan belajar CBL dengan strategi konflik kognitif memfasilitasi kesempatan mahasiswa dalam kolaborasi kelompok kecil untuk menyelesaikan tugas yang menantang, aktivitas berstatistika tidak hanya berfokus pada solusi akhir yang dicari, melainkan membangun pemahaman melalui proses berpikir antara lain mencakup tindakan mental yaitu: menafsirkan, conjecturing, menyimpulkan, membuktikan, menjelaskan, menerapkan, memprediksi, mengklasifikasi, mencari pemecahan masalah, pengujian hipotesis, serta estimasi hasil Gold dan Simons(2008).

Lebih jelas hasil penelitian Kalaian dan Kasim (2014) melakukan penelitian tentang pengaruh pembentukkan kelompok kecil untuk meningkatkan prestasi statistika siswa. Dalam penelitiannya dilakukan meta-analisis yang menunjukkan bahwa metode belajar kooperatif, kolaborasi dan penyelidikan dasar digunakan pada level kelas statistika di universitas. Hasil penelitian juga menunjukkan bahwa belajar secara kooperatif dan kolaboratif mendukung keefektivitasan pembelajaran dalam kelompok kecil.

Jadi secara keseluruhan, metode belajar dengan menggunakan kelompok kecil dapat meningkatkan nilai ujian statistika mahasiswa. sesuai ungkapan Maron, (2016); Susilawati, (2017) bahwa pembelajaran yang dilakukan kelompok kecil secara konstruktivis sosial, menciptakan, dan mengembangkan pengetahuan melalui tugas, bukan hasil menerima informasi dari pengajar saja, bahkan dalam kondisi modern secara profesional tidak bisa hanya mengandalkan pengetahuan yang diperoleh sendiri, keterlibatan pengajar dan mahasiswa lain merekonstruksi konsep materi pembelajaran untuk mengatasi konflik serta latihan menyelesaikan tugas yang berkesinambungan sangat dibutuhkan, untuk memenuhi tantangan dari permasalahan statistik.

Uji interaksi antara pembelajaran CBL dengan strategi konflik kognitif dan PAS terhadap 
kemampuan berpikir statistis, diperlukan pengujian hipotesis. Sebelum pengujian hipotesis, dilakukan uji normalitas terhadap kemampuan berpikir statistis berdasarkan PAS. Hasil uji normalitas, terdapat ketidaknormalan. Karena asumsi normalitas pada data gain kemampuan berpikir statistis tidak terpenuhi, maka uji interaksi tidak bisa dilakukan dengan ANOVA dua-jalur. Sebagai alternatif, bisa dilakukan kaidah nonparametrik dengan menggunakan Adjusted Rank Transform Test atau bisa juga dengan menggunakan Puri and Sen Aligned Ranks Technique (L Test) yang disempurnakan oleh Harwell \& Serlin menjadi Aligned RanksTechnique (L Test) in Trace Criterion Form (Susilawati 2017).

Pengujian hipotesis dengan menggunakan Adjusted Rank transform Test dilanjutkan dengan ANOVA dua jalur dengan kriteria pengujian, jika nilai Sig. lebih besar dari a, untuk a sebesar 0,05, maka $H_{0}$ diterima, sebaliknya jika nilai Sig. lebih kecil dari o,05, maka $H_{0}$ ditolak. Hasil rekapitulasi data pengujian interaksi antara pembelajaran CBL dengan strategi konflik kognitif dan PAS terhadap kemampuan berpikir statistis dapat dilihat pada Tabel dibawah ini.

Tabel 1. Uji Adjusted Rank Transform Test Interaksi antara Pembelajaran CBL dengan Strategi Konflik Kognitifdan PAS terhadap kemampuan Berpikir Statistis.

\begin{tabular}{|c|c|c|c|c|c|}
\hline \multicolumn{7}{|c|}{ Berpikir Statistis } \\
\hline Source & df & $\begin{array}{c}\text { Mean } \\
\text { Squaare }\end{array}$ & F & Sig & $\begin{array}{c}\text { Keput } \\
\text { usan }\end{array}$ \\
\hline Pembelajaran & 1 & $\begin{array}{c}1536,5 \\
54\end{array}$ & 35,984 & o,ooo & $\begin{array}{c}\text { Signifi } \\
\text { kan }\end{array}$ \\
\hline Level PAS & 2 & $\begin{array}{c}10810, \\
165\end{array}$ & $\begin{array}{c}253,16 \\
\text { o }\end{array}$ & o,ooo & $\begin{array}{c}\text { Signifi } \\
\text { kan }\end{array}$ \\
\hline $\begin{array}{c}\text { Pembelajaran } \\
\text { * Level PAS }\end{array}$ & 2 & $\begin{array}{c}733,93 \\
2\end{array}$ & 17,188 & o,ooo & $\begin{array}{c}\text { Ho } \\
\text { ditolak }\end{array}$ \\
\hline
\end{tabular}

Berdasarkan Tabel di atas untuk Jenis pembelajaran CBL dengan strategi konflik kognitif dan ekspositori secara bermakna memberikan pengaruh yang signifikan terhadap kemampuan berpikir statistis dengan nilai Sig. (0,000) lebih kecil dari 0.05. Hal yang sama juga terjadi pada level PAM yang secara signifikan memberikan pengaruh terhadap kemampuan berpikir statistis yang ditunjukkan dengan nilai Sig. (o,ooo dan 0,000) yang kurang dari 0,05. Untuk uji interaksi, berdasarkan jenis pembelajaran
CBL dengan strategi konflik kognitif dan Ekspositori dan level PAS terhadap kemampuan berpikir statistis terlihat bahwa nilai Sig. (o,00o) lebih kecil dari 0,05, sehingga disimpulkan menolak Ho. Berarti terdapat efek interaksi hubungan antara jenis pembelajaran pembelajaran CBL dengan strategi konflik kognitif dan Ekspositori dan level PAS (pandai, cukup, lemah), yang mempengaruhi kemampuan berpikir statistis mahasiswa.

Penulis interpretasikan bahwa jenis pembelajaranchallenge-based learning dengan strategi konflik kognitif yang digunakan dalam penelitian ini memberikan pengaruh terhadap peningkatan kemampuan berpikir statistis secara signifikan artinya pengaruhnya kecil, namun peningkatan kemampuan berpikir statistis, lebih banyak ditentukan oleh pengetahuan awal statistis (PAS) mahasiswa.

\section{KESIMPULAN}

Terdapat perbedaan rata-rata peningkatan kemampuan berpikir statistis antara mahasiswa yang memperoleh pembelajaran Challenge-based learning dengan strategi konflik kognitif dan pembelajaran ekspositori, dengan catatan sebagai berikut: Berdasarkan kriteria pengujian (N-gain) dapat disimpulkan bahwa peningkatan berpikir statistis mahasiswa yang mendapat pembelajaran CBL dengan strategi konflik kognitif (kategori cukup) lebih tinggi dari mahasiswa yang mendapat pembelajaran ekspositori. Berdasarkan PAS, peningkatan berpikir statistis mahasiswa kategori pandai yang mendapat pembelajaran CBL dengan strategi konflik kognitif lebih tinggi dari mahasiswa yang pembelajarannya ekspositori. Berdasarkan PAS, peningkatan berpikir statistis mahasiswa yang PAS kategori cukup yang mendapatkan pembelajaran CBL dengan strategi konflik kognitif lebih tinggi dari mahasiswa yang pembelajarannya ekspositori. Berdasarkan PAS, peningkatan berpikir statistis mahasiswa PAS kategori lemah yang mendapatkan pembelajaran CBL dengan strategi konflik kognitif lebih tinggi dari mahasiswa yang pembelajarannya ekspositori. Terdapat pengaruh interaksi antara pendekatan pembelajaran challenge-based learning dengan strategi konflik kognitif dan 
pembelajaran ekspositori serta PAS terhadap kemampuan berpikir statistis mahasiswa.
Terimakasih: Bantuan Dana dari DIPABOPTAN UIN SGD Bandung Tahun Anggaran 2016.

A framework for characterizing students' statistical thinking. Journal Mathematical Thinking and Learning, 2, 269-308.

Chance, B. L. (2002), Components of statistical thinking and implications for instruction and assessment. Journal of statistical education, 10. (3). 21-35.

Choi, H. J., \& Johnson, S. D. (2005). The effect of context-based video instruction on learning and motivation in online courses. American Journal of Distance Education, 19 (4), pp. 215-227.

DelMas, Robert C. (2002). Statistical Literacy, Reasoning, and Learning: A Commentary. Journal of Statistiks Education, 10 (3).

Diezmann, C, M. (2005). Challenging mathematically gifted primary students. Australasian Journal of Gifted Education, 14(1), pp. 50-57.

Eunsil, C., Jiyoung, L., \& Haeyoung, K. (2014). Statistical methods used in articles published by the journal of periodontal and implant Science. Journal of of Periodontal and Implant Science, 44(06), 288-292.

Garfield, J., \& Ahlgren, A. (1988), Diffieculties in learning basic concepts in probability and statistics: implications for research. Journal for research in mathematics education Vol. 19 No.1.

Garfield, J. (1995), How students learn statistics. Journal international statistical review. 63. (1). 25-34.

Jones, G.A., Langrall, C. W., Thornton, C. A., \& Mogill, A.T (1999), Students probabilistic thinking in instruction. Journal for research in mathematics education, 30, 487-519.

Jones, G.A., Thornton, C.A., Langrall, C.W., Mooney, E., Perry, B., \& Putt, I. (2000).
Jones, G.A., Langrall, C.W., Thornton, C.A., Mooney, E.S., Wares, A.S., Jones, M.R., Perry, B., Putt, I.J., \& Nisbet, S. (2001). Using students' statistical thinking to inform instruction. Journal of Mathematical Behavior, 20, 109-144.

Kalaian, S. A., \& Kasim, R. M. (2014). A metaanalytic review of studies of the effectiveness of small-group learning methods on statistics achievement. Journal of Statistics Education, 22(1)

Lee, G., Kwon, J., Park, S. S., Kim, J. W., Kwon, H.G.,\& Park, H. K. (2003). Developmentof an instrument for measuring cognitive conflik in secondary-levelscience classes. Journal of Research in Science Teaching. Vol 40, No. 6, pp.19-27.

Maron, A, I. (2016). Priorities of teaching mathematics in universities IEJMEInternational Electronic Journal of Mathematics Education, 11 (9), pp. 3339-3350.

Shabiralyani, G., Hasan, K. S., Hamad, N., \& Iqbal, N. (2015). Impact of visual aids in enhancing the learning process case research: district dera ghazi khan. Journal ofEducation and Practice, 19(6), 226-223.

Shaidullina, A. R., Pavlova, N. A., Minsabirova, V. N., Burdukovskaya, E. A., Yunusova, A. B., Letyaev, V. A., Afanasev, A. S. (2015b) Integration processes in education: classification of integration types. JournalReview of European Studies, 7(4), 27-31.

Surijah, A, E., Anggara, Yanti, Sari, Hartika, Ramayanti, Sugiri, (2018) Komik 
sebagai media pembelajaran statistika.

Jurnal Psikologi Insight, 2 (2), 39-50

Susilawati, W., Suryadi, D,. \& Dahlan, J. A. (2017). The improvement of mathematical spatial visualization ability of studentthrough cognitive conflict strategy.International Electronic Journal of Mathematics Education (IEJME-ISSN: 1306-3030). Vol.12 (5), pp. 155-166.

\section{Buku}

Ben-Zvi, D \& Friedlander, A. (2010), Statistical a technological environment. rehovot, Israel: the weizmann institute of science.

Garfield, J. (1999), Thinking about statistical reasoning, thinking, and literacy. paper presented at firstnannual rountable on statistical thinking, reasoning, and literacy.

Gold, B., Simons, R. A. (2008).Proof and other dilemmas mathematics and Philosophy. The Mathematical Association qf America. Inc.

Johnson, Laurence F.; Smith, Rachel S.; Smythe, J. Troy; Varon, Rachel K. (2009). Challenge-based learning: an approach for our time. Austin, Texas: The New Media Consortium.

\section{Prosiding}

Verhoeven, P. (2006) Statistics education in the Netherlands and flanders: an outline of introductory courses at universitas and colleges. in icots-7 conference proceedings.

\section{Disertasi}

Ismaimuja (2009), Kemampuan berpikir kritis dan kreatif matematis siswa SMP melalui pembelajaran berbasis masalah dengan strategi konflik kognitif.Disertasi UPI Bandung. Tidak dipublikasikan

Martadiputra, B.A.P. (2012), Meningkatkan kemampuan berpikir statistik mahasiswa $\mathrm{S} 1$ pendidikan matematika melalui pembelajaran meas yang dimodifikasi. Disertasi PPS UPI tidak dipublikasikan.

Susilawati, W. (2017) Pengaruh pembelajaran berbasis tantangan dengan strategi konflik kognitif terhadap peningkatan kemampuan visualisasi spasial, berpikir lateral dan kegigihan matematis mahasiswa. Bandung. DisertasiPPS UPI. 